\title{
MORPHOMOLECULAR CHARACTERIZATION OF Pleurotus ostreatus (JACQ. FR.) KUMMER STRAINS IN RELATION TO LUMINOSITY AND TEMPERATURE OF FRUTIFICATION
}

\author{
Regina Helena Marino ${ }^{1 *}$; Augusto Ferreira da Eira ${ }^{1}$; Eiko Eurya Kuramae ${ }^{1}$; Elvio Cardoso \\ Queiroz $^{1}$ \\ ${ }^{I}$ UNESP/FCA - Depto. de Produção Vegetal, C.P.237 - 18603-970 - Botucatu, SP - Brasil. \\ *Corresponding author <rehmarino@bol.com.br>
}

\begin{abstract}
Temperature is one of the main factors affecting mushrooms development and introduction in new areas. Effects of temperature $\left(15^{\circ} \mathrm{C}\right.$ and $\left.28^{\circ} \mathrm{C}\right)$ and luminosity $(120$ and $900 \mathrm{lux})$ were evaluated for eight P. ostreatus strains in relation to precocity, yield, pileus area, stalk formation pattern, coloration and handling resistance. Genetic variability of strains was analysed by the Random Amplified Polymorphic DNA (RAPD) method. The Pos $98 / 37$ strain was the only to yield white pileus at $28^{\circ} \mathrm{C}-900$ lux, and grey ones at $15^{\circ} \mathrm{C}$ and 120 lux. The Pos $96 / 05$ strain, the latest, produced lead-coloured pileus at $15^{\circ} \mathrm{C}$, as did the remaining strains at this temperature. Strains cultivated at $15^{\circ} \mathrm{C}$ did not differ in relation to handling resistance. At $28^{\circ} \mathrm{C}$ mushrooms were less resistant. In relation to yield, the Pos 98/38 strain was significantly more efficient. The Pos $98 / 37$ strain, at $28^{\circ} \mathrm{C}$, as compared to the same strain at $15^{\circ} \mathrm{C}$, was more efficient and had an asymmetric stalk formation pattern. Among strains cultivated at $15^{\circ} \mathrm{C}$, the stalk formation pattern was symmetric, except for the Pos 97/15 and Pos 97/17 strains. Molecular characterization of the Pos 98/37 strain was 30\% similar to the remaining strains. The temperature of fructification and luminosity influence the induction and development of the isolates.
\end{abstract}

Key words: mushrooms, temperature, morphology of basidiocarps, yield and marked RAPD

\section{CARACTERIZAÇÃO MORFOMOLECULAR DE ISOLADOS DE Pleurotus ostreatus (JACQ. FR.) KUMMER EM RELAÇÃO À LUMINOSIDADE E TEMPERATURA DE FRUTIFICAÇÃO}

\begin{abstract}
RESUMO: A temperatura é um dos principais fatores que influenciam o desenvolvimento e a introdução de cogumelos em nova áreas. $\mathrm{O}$ efeito da temperatura $\left(15^{\circ} \mathrm{C}\right.$ e $\left.28^{\circ} \mathrm{C}\right)$ e a luminosidade $(120$ e 900 lux $)$ foram avaliados em oito isolados de $P$. ostreatus quanto à precocidade, eficiência biológica, área do pileus, padrão de formação das pencas, coloração e resistência ao manuseio. A variabilidade genética dos isolados foi analisada pelo método "Random Amplified Polymorphic DNA" ou DNA polimórfico amplificado ao acaso (RAPD). O isolado Pos $98 / 37$ foi o único a produzir a $28^{\circ} \mathrm{C}$ e 900 lux, apresentando píleo branco nessa temperatura e cinza a $15^{\circ} \mathrm{C}$ e 120 lux. O isolado Pos 96/05, o mais tardio, apresentou píleo chumbo a $15^{\circ} \mathrm{C}$ a 120 lux, assim como os demais isolados nesta temperatura. Os isolados cultivados a $15^{\circ} \mathrm{C}$ não diferiram quanto à maior resistência ao manuseio, enquanto a $28^{\circ} \mathrm{C}$, os cogumelos obtidos foram mais frágeis. Quanto à eficiência biológica, o isolado Pos $98 / 38$ foi mais eficiente. O isolado $98 / 37$ a $28^{\circ} \mathrm{C}$, comparado com o mesmo isolado a $15^{\circ} \mathrm{C}$, foi mais eficiente e apresentou padrão de formação de pencas assimétrico. Entre os isolados cultivados a $15^{\circ} \mathrm{C}$, o padrão de formação de pencas foi similar exceto nos isolados Pos 97/15 e Pos 97/17. Na caracterização molecular, o isolado Pos 98/37 apresentou 30\% de similaridade com os demais. A temperatura de frutificação e a intensidade luminosa influenciaram a indução e o desenvolvimento dos isolados.

Palavras-chave: cogumelos, temperatura de produção, morfologia dos basidiocarpos, eficiência biológica e marcador RAPD
\end{abstract}

\section{INTRODUCTION}

Pleurotus ostreatus is an edible fungus of great biotechnological interest, not only for its ability to grow on numerous agricultural residues to produce mushrooms of high organoleptical quality (Rajarathnam \& Bano, 1987), but also because this fungus produces secondary metabolites with pharmaceutical applications and some proteins of industrial use - amino acids, vitamins, etc. These properties significantly increased its commercial value in the last years (Bunyard et al., 1996; Zervakis \& Balis, 1996).

P. ostreatus is extensively produced out in localities with average temperature of $15^{\circ} \mathrm{C}$ (Zadrazil, 1978). There is, however, a variety of $P$. ostreatus from Thailand, which grows in temperatures above $25^{\circ} \mathrm{C}$ and is 
considered to be $P$. ostreatus var. Florida, described by Eger et al. (1976) and Eger (1978), since it presents cream-coloured to white pileutables, and sexual compatibility with the Japanese isolate of $P$. ostreatus (Kinugawa et al., 1997).

The coloration of the pileus is probably related to luminous intensity (Durand, 1976). The coloration of "Shiitake" mushrooms (Lentinula edodes) is a characteristic associated to the interactive effect of the temperature and luminous intensity (Przybylowicz \& Donoghue, 1990).

The objective of this work was to describe the morphomolecular characteristics of $P$. ostreatus isolates in relation to luminosity and temperature in axenic culture, evaluating its precocity, biological efficiency, pileus area, stalk formation pattern, coloration, handling resistance and molecular characteristics of the isolates, using Random Amplified Polymorphic DNA (RAPD) method.

\section{MATERIAL AND METHODS}

Eight isolates of $P$. ostreatus (cultures covered with mineral oil) were used in this experiment carried out in Botucatu, SP, Brazil (22 $53^{\prime} 09^{\prime \prime}$ S and $48^{\circ} 26^{\prime} 42^{\prime \prime} \mathrm{W}$ ) (Table 1). They were obtained from growers and from reisolates of the based context of basidiocarp and, under aseptic conditions multiplied in culture media based on sawdust-dextrose-agar (SDA) and incubated at $25^{\circ} \mathrm{C}$ for seven days (Eira \& Minhoni, 1997).

The substrate consisted of sawdust (49.8\%), wheat bran $(20 \%)$, rice bran $(20 \%)$, sugarcane bagasse $(10 \%)$ and lime $(0.2 \%)$. The mixture was conditioned in bottles, with the standardization of 400 and autoclaved at $120^{\circ} \mathrm{C}$ during 4 hours. Inoculation was achieved through the transference of $0.5 \mathrm{~cm}$ diameter circle of culture medium (Eira \& Minhoni, 1997) colonized in the bottles with the sterilized sawdust-based substrate. Inoculation was performed in an aseptic chamber and at the temperature of $25^{\circ} \mathrm{C}$ for 30 days, without light.

After incubation, primordium induction was made by taking off the coverage and adding 2 to $3 \mathrm{~cm}$ of water during 4 hours, without thermal shock. Treatments consisted of, (1) $15 \pm 5^{\circ} \mathrm{C}, 120$ lux (photoperiod of 12h) and 85 to $90 \%$ relative humidity and (2) $28 \pm 5^{\circ} \mathrm{C}, 900$ lux (photoperiod of 24h) and 85 to $90 \%$ relative humidity, set in a completely randomized design $(\mathrm{n}=10)$ (bottles with 400 of humid substrate). Parameters for analyses were: primordium formation and harvest (days), biological efficiency (grams of fresh mushrooms/grams of dry substrate $\mathrm{x} 100$ ), coloration of the pileus at harvest (visual analysis), size of the harvested basidiocarps (photographic analysis) and handling resistance evaluated by the presence of breakable pileus (easily broken or firm).

Each isolate was photographed after the harvest with a $640 \times 480$ pixel resolution digital camera. Digital analysis evaluated pileus area, which was related to temperature of fructification, trying to establish a stalk formation pattern and the intensity of coloration of the pileus given by the number of pixels in the grey scale $(0$ - black to 250 - white), using the Image Tool program (Celso, 1999). The fructification pattern was studied through the analysis of frequency, asymmetry and curtose, criming to separate the isolates of greater similarity.

The process of differentiation of the genetic material of the isolates followed the RAPD method described by Williams et al. (1990). The genonic DNA was extracted as suggested by Sadowsky et al. (1987) and Kuramae-Izioka (1997). Amplification reactions were performed using a DNA thermal cycler (MJ Research), programmed according to Sambrook et al. (1989). The samples and the Ladder $1 \mathrm{~Kb}$ (Gibco BRL Life Technologies, Inc.) molecular marker were applied to $1.5 \%$ agarose gel using the TBE buffer $\left(0.1 \mathrm{~mol} \mathrm{~L}^{-1}\right.$ Tris- $\mathrm{HCl} ; 0.1$ mol boric acid $\mathrm{L}^{-1} ; 0.02 \mathrm{~m} \mathrm{~mol} \mathrm{~L}^{-1}$ EDTA; $\mathrm{pH}$ 8.0). The eletrocphoresis ran on approximately $120 \mathrm{~V}$ for 3 hours. The gel was photographed using ultraviolet light. The genetic similarity between the isolates was calculated using program Numerical Taxonomy and Multivariate Analysis System (NTSYS), with the coefficient "simple matching" (SM) and the construction of the dendrogram for the Unweighted Pair-Group method Arithmetic Average (UPGMA) method.

Table 1 - Origin of $P$. ostreatus isolates used in the experiments.

\begin{tabular}{|c|c|c|c|c|}
\hline Collection code & Origin & Geographic coordenates & Temperature of fructification & Color of pileus \\
\hline Pos $96 / 05$ & Arujá - SP & $46^{\circ} 19^{\prime} 15^{\prime \prime} \mathrm{W}$ & 10 to $15^{\circ} \mathrm{C}$ & dark grey \\
\hline Pos $97 / 12$ & Moji das Cruzes - SP & $23^{\circ} 31^{\prime} 22^{\prime \prime S} \quad 46^{\circ} 11^{\prime} 18^{\prime \prime} \mathrm{W}$ & 10 to $15^{\circ} \mathrm{C}$ & dark grey \\
\hline Pos $97 / 14$ & São Roque - SP & $23^{\circ} 31^{\prime} 45^{\prime \prime S} \quad 47^{\circ} 08^{\prime} 07^{\prime \prime} \mathrm{W}$ & 10 to $15^{\circ} \mathrm{C}$ & dark grey \\
\hline Pos $97 / 15$ & São Paulo - SP & $23^{\circ} 32^{\prime} 51^{\prime \prime S} \quad 46^{\circ} 38^{\prime} 10^{\prime \prime W}$ & 10 to $15^{\circ} \mathrm{C}$ & dark grey \\
\hline Pos $97 / 17$ & Brasília - DF & $15^{\circ} 46^{\prime} 47^{\prime \prime S} \quad 47^{\circ} 55^{\prime} 47^{\prime \prime W}$ & 10 to $15^{\circ} \mathrm{C}$ & dark grey \\
\hline Pos $98 / 37$ & Moji das Cruzes - SP & $23^{\circ} 31^{\prime} 22^{\prime \prime S} \quad 46^{\circ} 11^{\prime} 18^{\prime \prime W}$ & $\mathrm{n}$ & white \\
\hline Pos $98 / 38$ & São Paulo - SP & $23^{\circ} 32^{\prime} 51^{\prime \prime S} \quad 46^{\circ} 38^{\prime} 10^{\prime \prime} \mathrm{W}$ & 10 to $15^{\circ} \mathrm{C}$ & dark grey \\
\hline Pos $98 / 40$ & Moji das Cruzes - SP & $23^{\circ} 31^{\prime} 22^{\prime \prime S} \quad 46^{\circ} 11^{\prime} 18^{\prime \prime W}$ & 10 to $15^{\circ} \mathrm{C}$ & dark grey \\
\hline
\end{tabular}

n - not known 


\section{RESULTS AND DISCUSSION}

The isolate of $P$. ostreatus cultivated at $15^{\circ} \mathrm{C}$ was later in relation to the period of formation of primordium and harvest. Isolate Pos 98/37 was the only isolate that fruited at $28^{\circ} \mathrm{C}$ (Table 2). The reduction of the metabolism of microorganisms under low temperature was already expected, as mentioned for Zadrazil (1978). The use of isolate of $L$. edodes not adapted to tropical regions does not form primordia, similarly to what occurred at $28^{\circ} \mathrm{C}$ with isolates of $P$. ostreatus, except for Pos 98/37 (Chang et al., 1995). This behavior is credited to the use of isolates introduced by Japanese immigrants for the commercial production of P. ostreatus (Eira \& Minhoni, 1997) mushrooms. Isolates from Japan are commercially cultivated at an average $15^{\circ} \mathrm{C}$ (Kinugawa et al., 1997). Isolates of $P$. ostreatus var. Florida are adapted to an average $25^{\circ} \mathrm{C}$, and produce pileus cream to white coloured (Eger et al., 1976). Kinugawa et al. (1997) also recorded an isolate similar the P. ostreatus var. Florida in Thailand with these characteristics. In this work, isolate Pos 98/ 37 at $28^{\circ} \mathrm{C}$ and 900 lux presented white pileus, as mentioned by Kinugawa et al. (1997) for isolate of P. ostreatus of Thailand and by Eger et al. (1976) for P. ostreatus var. Florida. At $15^{\circ} \mathrm{C}$ and 120 lux (Table 2), all isolates presented pileus with colorations changing from grey to lead, same as observed by Eger et al. (1976) and Kinugawa et al. (1997) in studies with P. ostreatus at $15^{\circ} \mathrm{C}$.

Producing mushroom "Shiitake" at low temperature needs less luminosity than at high temperature (Przybylowicz \& Donoghue, 1990). This behavior was also observed for isolate of $P$. ostreatus at $15^{\circ} \mathrm{C}$, when a luminous intensity of 120 lux was enough to induce the coloration of the pileus of all isolates. On the other hand, only the isolate that fruited at $28^{\circ} \mathrm{C}$ (Pos 98/37), with the luminous intensity of $900 \mathrm{lux}$, did not present coloration of the pileus, remaining white (Table 2 and Figure 1).
Similarly, in parallel experiments, P.ostreatus activated at with luminous intensity of 120 lux and $28^{\circ} \mathrm{C}$ did not present pileus coloration. But at $15^{\circ} \mathrm{C}$ with luminous intensity of 900 lux, the eight isolates of $P$. ostreatus presented reduction of coloration with the increase of the luminosity (results not presented), evidencing the importance of the interaction temperature vs. isolate vs. luminous intensity. This color variation is very frequent in the species and depends on environmental conditions, as reported by Rajarathnam \& Bano (1987) and Eger et al. (1974).

Edible mushrooms cultivated between $15-20^{\circ} \mathrm{C}$ present better quality and durability than those at $25^{\circ} \mathrm{C}$ (Eger et al., 1976; Przybylowicz \& Donoghue, 1990). An example was observed in this work in relation to the handling resistance after harvest (Table 2).
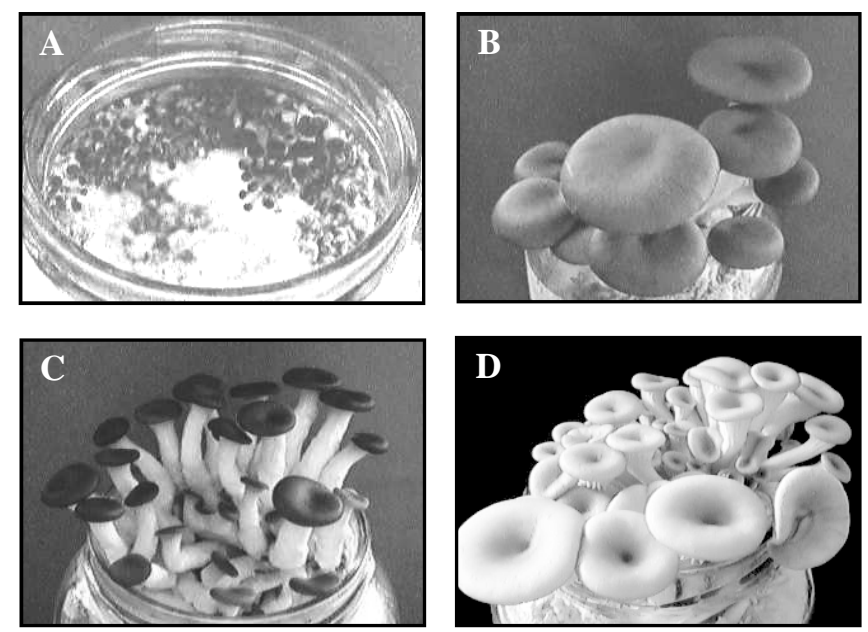

Figure 1 - $P$. ostreatus basidiocarps in production conditions. A- Isolated Pos $96 / 0515^{\circ} \mathrm{C}, 120$ lux, after 11 days of the hydration. B - Isolated Pos $98 / 3815^{\circ} \mathrm{C}, 120$ lux, after 7 days of the hydration. C - Isolated Pos $98 / 3715^{\circ} \mathrm{C}, 120$ lux, after 11 days of hydration. D - Isolated 98/37 Pos $28^{\circ} \mathrm{C}, 900$ lux, after 7 day of the hydration

Table 2 - Period of formation of primordium, harvest, biological efficiency, coloration of the pileus and handling resistance of $P$. ostreatus mushrooms in relation to temperature and luminosity.

\begin{tabular}{|c|c|c|c|c|c|c|}
\hline Temp $^{1} . /$ Luminosity $^{2}$ & Isolate & Primordium & Harvest & EB4 & Color of pileus & Handling resistance \\
\hline & & \multicolumn{2}{|c|}{ - } & $\%$ & & \\
\hline \multirow[t]{4}{*}{$28^{\circ} \mathrm{C} / 900 \mathrm{Lux}$} & Pos $98 / 37$ & $2.0 \mathrm{~b}$ & $7.0 \mathrm{~b}$ & $35.8 \mathrm{~b}$ & white & breakable \\
\hline & Pos 96/05 & $10.5 \mathrm{a}$ & $14.5 \mathrm{a}$ & $11.6 \mathrm{c}$ & lead-grey & firm \\
\hline & Pos $97 / 12$ & $9.0 \mathrm{a}$ & $14.0 \mathrm{a}$ & $17.7 \mathrm{c}$ & lead-grey & firm \\
\hline & Pos $97 / 14$ & $9.0 \mathrm{a}$ & $13.0 \mathrm{a}$ & $17.2 \mathrm{c}$ & lead-grey & firm \\
\hline \multirow[t]{5}{*}{$15^{\circ} \mathrm{C} / 120 \mathrm{Lux}$} & Pos $97 / 15$ & $9.0 \mathrm{a}$ & $13.0 \mathrm{a}$ & $11.4 \mathrm{c}$ & lead-grey & firm \\
\hline & Pos $97 / 17$ & $8.0 \mathrm{a}$ & $13.0 \mathrm{a}$ & $16.2 \mathrm{c}$ & lead-grey & firm \\
\hline & Pos $98 / 37$ & $8.0 \mathrm{a}$ & $13.0 \mathrm{a}$ & $22.3 \mathrm{c}$ & grey & firm \\
\hline & Pos $98 / 38$ & $8.0 \mathrm{a}$ & $13.0 \mathrm{a}$ & $43.1 \mathrm{a}$ & dark grey & firm \\
\hline & Pos $98 / 40$ & $8.0 \mathrm{a}$ & $13.0 \mathrm{a}$ & $24.2 \mathrm{c}$ & lead-grey & firm \\
\hline
\end{tabular}

${ }^{1}$ Average temperature; ${ }^{2}$ Average luminous intensity; ${ }^{3}$ Medians in the same column followed by distinct letters differ by Dunn Test $(P<0.05) ;{ }^{4} \mathrm{~EB}$ : biological efficiency. 
Isolate Pos $98 / 37$ presented greater biological efficiency (EB) at $28^{\circ} \mathrm{C}$ than at $15^{\circ} \mathrm{C}$. The isolates Pos 97/ 15 and $\mathrm{Pos} 98 / 38$ presented, at $15^{\circ} \mathrm{C}$, respectively, the lowest and the highest values of EB. However, isolate Pos 98/38 was harvested after the established commercial pattern what, in part, can explain the high values of EB (Table 2). The commercial pattern of mushrooms with pileus area up to $150 \mathrm{~mm}^{2}$ increases their value. In this experiment, isolates Pos 98/37, Pos 98/38 and Pos 98/40 at $15^{\circ} \mathrm{C}$ and $\mathrm{Pos} 98 / 37$ at $28^{\circ} \mathrm{C}$ were harvested after reaching the commercial pattern (Figure 2).

The fructification temperature influenced the pattern of stalk formation of mushrooms, therefore isolate Pos $98 / 37$ cultivated at $28^{\circ} \mathrm{C}$ presented greater formation of primordium as compared to $15^{\circ} \mathrm{C}$. Isolates Pos $97 / 15$, Pos 97/17 and Pos 98/40 also presented high concentration of primordium, with uniform distribution of mushrooms in relation to stalk formation pattern and area. In a similar way, isolate Pos 98/38, harvested after reaching the commercial pattern, presented uniform stalk formation patterns (Figure 2). Pos 98/37 of P. ostreatus (white variety and the only to fructify at $28^{\circ} \mathrm{C}$ ), presented polymorphism with $30 \%$ of genetic similarity in relation to isolated adapted to $15^{\circ} \mathrm{C}$ for production (Figure 3). Isolate Pos 98/37 also was certified as P. ostreatus (Meijer ${ }^{1}$, 2000).

The presence of polymorphism and minor similarity between isolates Pos 98/37 and all other, is probably related to the existence of genes important to the tolerance to high temperatures, as observed by $\mathrm{Li}$ (1980) and cited by Müller (1988) for some isolates of P. ostreatus, which have seven dominant genes, inherited from gen-

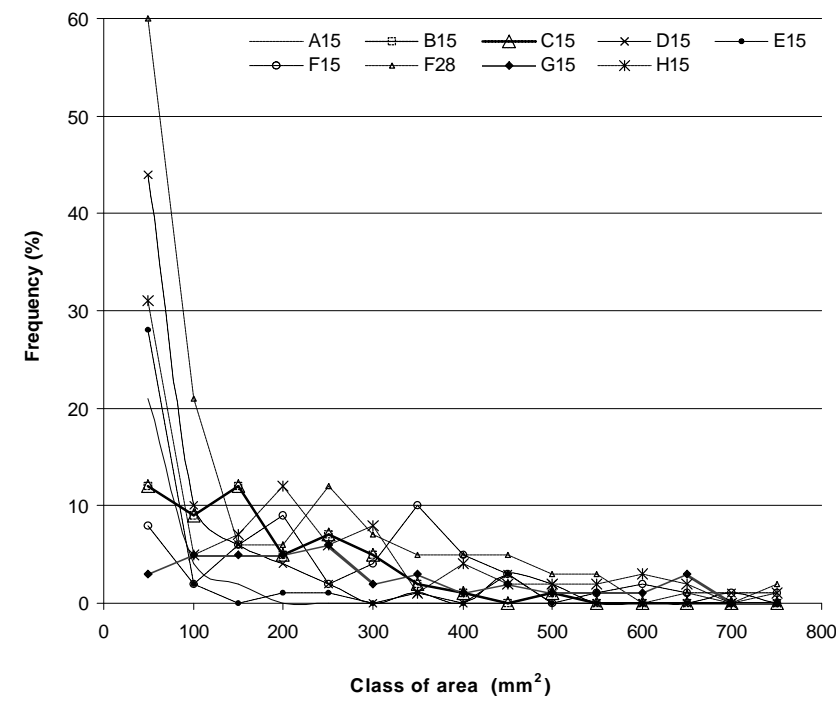

Figure 2 - Basidiocarp distribution according to the pileus area of eight isolates of P. ostreatus, at the fructification $\left(15^{\circ} \mathrm{C}\right)$ and isolated $\left(28^{\circ} \mathrm{C}\right)$.

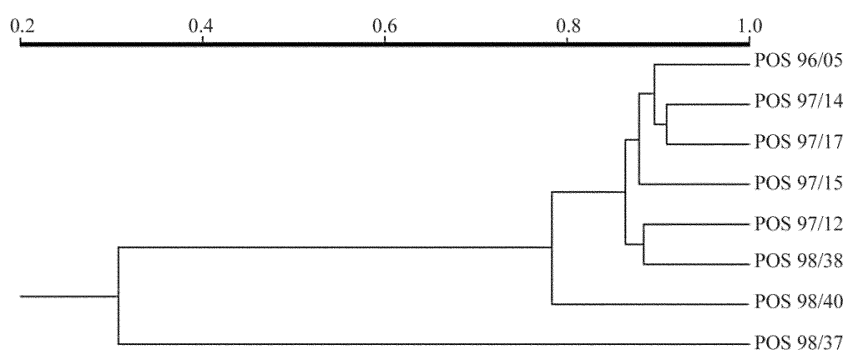

Figure 3 - Dendrogram generated to group UPGMA, based on the Coefficient of "Simple Matching", from the bands for RAPD with primers OPA-13, OPA-18, OPG-15, OPP07 and OPG-14, in isolates analyses of $P$. ostreatus.

eration to generation, related to the resistance to heat (Guinberteau et al., 1991; Callac et al., 1998) report the presence of genes responsible for the induction of primordium and other genes related to the coloration of the basidiocarps. These authors indicated that the genetic control of the pileus coloration is given by a monogenic, dominant factor, while the white color or without coloration is related to recessive alleles. However, considering pileus coloration, the temperature effect has also to be taken into consideration since isolate Pos 98/37, cultivated at $28^{\circ} \mathrm{C}$ had white pileus, but at $15^{\circ} \mathrm{C}$ became grey. Thus, the genetic manifestation of each isolate is influenced by temperature and luminous intensity (qualitative evaluation of the isolates), leaving aside other factors not studied herein.

On the other hand, as observed by Larraya et al. (1999), the other isolates of $P$. ostreatus were similar, indicating low genetic variability, which can result in a production risk, specially, in cases of biotic or abiotic stress. Therefore, among the isolates used in this experiment, Pos 98/37 have great importance for genetic improvement programs which aim precocious and heat tolerant isolates, behaving with commercially desirable morphologic characteristics, such as those described by Pahil et al. (1991), for an isolate of Agaricus bitorquis that, in addition to fructifying at $25^{\circ} \mathrm{C}$, presented good commercial quality.

\section{ACKNOWLEDGMENTS}

\section{To FAPESP, Project 97/14675-5.}

\section{REFERENCES}

BUNYARD, B.A.; CHAICHUCHOTE, S.; NICHOLSON, M.S.; ROYSE, D.J. Ribosomal DNA analysis for resolution of genotypic classes of Pleurotus. Mycological Research, v.2, p.143-150, 1996.

CALLAC, P.; MOQUER, F.; IMBERNON, M.; GUEDES-LAFARGUE, M.R.; MAMOUN, M.; OLIVIER, J.M. Evidence for PPC1, a determinant of the pilei-pellis color of Agaricus bisporus fruitbodies. Fungal Genetics and Biology, v.23, p.181-188, 1998.

CELSO, P.G. Interações entre Agaricus bisporus e microrganismos termófilos isolados do substrato de cultivo do cogumelo. Araraquara: UNESP/IQ, 1999. 83p. (Dissertação - Mestrado)

${ }^{1}$ Meijer, A. de - Technical of the Bank of Germoplam of the Embrapa Forests, Curitiba, Paraná, Brazil. 
CHANG, S.T.; KWAN, H.S.; KANG, Y.N. Colletion, characterization, and utilization of germ plasm of Lentinula edodes. Canadian Journal of Botany, n.73, p.955-961, 1995, Supplement 1.

DURAND, R. Influence des radiations luminuses sur les processus de reproduction des champignons: hypotheses sur lidentite des photorecepteurs: revue bibliographique. Mycologia, v.60, p.3-16, 1976.

EGER, G.; GOTTWALD, H. D.; VON NETZER, U. The action of light and other factors on sporophore initiation in Pleurotus ostreatus. Mushroom Science, v.9, p.575-583, 1974.

EGER, G.; EDEN, G.; WISSING, E. Pleurotus ostreatus, breeding potential of a new cultivated mushroom. Theoretical and Applied Genetics, v.47, p. $155-163,1976$.

EGER, G. Biology and breeding of Pleurotus. In: CHANG, S.T.; HAYES, W.A. (Ed.) The biology and cultivation of edible mushrooms. New York: Academic Press, 1978. cap.24, p.497-519.

EIRA, A.F.; MINHONI, M.T.A. Manual teórico-prático do cultivo de cogumelos comestíveis. 2.ed. Botucatu: Fundação de Pesquisa Agropecuária e Florestais, 1997. 115p.

GUINBERTEAU, J.; OLIVIER, J.M.; TANNE, M.N. Improvement of Lepista species cultivation, technical factors, and selection of strains. Mushroom Science, v.2, p.615-621, 1991.

KINUGAWA, K.; TANESAKA, E.; NAGATA, A.; WATANABE, K. Crosscompatibility between Thai and Japanese Oyster mushrooms and the inheritance of fruiting habits. Memoirs of the Faculty of Agriculture of Kinki University, n.30, p.7-11, 1997.

KURAMAE-IZIOKA, E.E. A rapid, easy and high yield protocol for total genomic DNA isolation of Colletotrichum gloesporioides and Fusarium oxysporum. Revista Unimar, v.19, p.683-689, 1997.

LARRAYA, L.; PEÑAS, M.M.; PÉREZ, G.; SANTOS, C.; RITTER, E.; PISABARRO, A.G.; RAMÍREZ, L. Identification of incompatibility aleles and characterisation of molecular markers genetically linked to the A incompatibility locus in the white rot fungus Pleurotus ostreatus. Current Genetic, v.34, p.486-493, 1999.
MÜLLER, J. Genetic potencial of Pleurotus ostreatus: relevance to the disposal of agro-wastes. Micological Neotropical Aplicada, v.1, p.2944, 1988.

PAHIL, V.S., SMITH, J.F.; ELLIOTT, T.J. The testing and improvement of high temperature, wild Agaricus strains for use in tropical and subtropical climates. Mushroom Science, v.2, p. 589-599, 1991.

PRZYBYLOWICZ, P.; DONOGHUE, J. Shiitake growes handbook. 2.ed. New York: Hunt Publishing Co, 1990. 217p.

RAJARATHNAM , S.; BANO, Z. Pleurotus mushrooms. Parte 1 A: Morfology, life cycle, taxonomy, breeding and cultivation. CRR Critical Recviews in Food Science, v.26, p.157-223, 1987.

SADOWSKY, M.J.; TULLY, R.E.; CREGAN, P.B.; KEYSER, H.H. Genetic diversity in Bradyrhizobium japonicum serogroup 123 and relation to genotype specific nodulation of soybean. Appllied and Environmental Microbiolology, v.53, p.2624-2630, 1987.

SAMBROOK, J.; FRITSCH, E.F.; MANIATIS, T. Molecular cloning: a laboratory manual. 2.ed. New York: Academic Press, 1989.

WILLIAMS, J.G.; KUBELIK, A.R.; LIVAK, K.J.; RAFALSKI, J.A.; TINGEY, S.V. DNA polymorphisms amplified by arbitrary primers are useful as genetic markers. Nucleic Acids Research, v. 18, p.6531-5, 1990

ZADRAZIL, F. Cultivation of Pleurotus. In: CHANG, S.T.; HAYES, W.A (Ed.) The biology and cultivation of edible mushrooms. New York: Academic Press, 1978. cap.25, p.521-557.

ZERVAKIS, G.; BALIS, C. A pluralistic approach in the study of Pleurotus species with emphasis on compatibility and physiology of the European morphotaxa. Mycological Research, v.10, p.717-731, 1996

Received January 04, 2002

Accepted June 10, 2003 